\title{
Social Work Education in Vietnam: Trajectory, Challenges and Directions
}

\author{
Kham Van Tran \\ Hanoi University of Social Sciences and Humanities, Vietnam National University-Hanoi, Vietnam \\ *Corresponding Author: khamtv@ussh.edu.vn
}

\begin{abstract}
In spite of the long history, of social work-oriented activities, Vietnam's social work education dates back to the 1980s as the policy of Doi Moi (Renew) was applied which required the comprehensive and systematic transformation in Vietnam. In the early 1990s, some academic institutions in Vietnam introduced the subjects of social work in the curriculum and trained social work students in related programs. However, such training was not focused and dispersed, and social work education really emerged in Vietnam in 2004 when the Ministry of Education and Training approved the national curriculum for social work. At the turn of 2010, Vietnam Government supported the urgent need for social work professionals to solve various social problems and to build the welfare, democracy of the socialist state. Since then, Vietnam's social work education has developed rapidly. Currently there are around 50 universities and colleges in the national and provincial levels that are offering social work programs. Social work education in Vietnam is facing challenges in different aspects. This paper aims at exploring the voices of social work students on social work education challenges in different layers of education, licensing, materials, practicum and from students themselves, based on a survey of 17 universities in Vietnam. The paper also aims at providing suggestions for maintaining the social work education in Vietnam with professional training direction.
\end{abstract}

Keywords Education, Social Work Education, Social Workers, Social Development, Social Work

\section{Introduction}

While social work has its long history of development in Western countries, it is still a new profession in Vietnam. The undergraduate program in social work was officially approved in 2004 by Ministry of Education and Training (MOET). At present 50 universities and colleges have permission for training at the undergraduate and masters' levels (Bộ Giáo dục và Đào tạo 2013). The concerns on delivering and promoting social work education have been a significant sign for certain role of social work on social development and human welfare in Vietnamese context. The Government and the related ministries and organisations in Vietnam were very active in developing initiatives and plans for promoting social work education and practice nationwide. The strategies for social work development from 2010-2020, the decision on employment code for social workers and support workers, the establishment of social worker network, annual workshops on social work education are the specific examples of the prospects for social work development in the future.

At this early stage, social work education in Vietnam has been facing many challenges: from awareness of this professional job, to the lack of learning materials, practicum places, staff and skills on supervisions as well as the teaching staff on social work (Hugman, Lan \& Hong 2007). However, in the era of critical social development strategy and welfare reform from 2010-2020, social work also gets significant social concerns and opportunities for its development professionally. In these strategies, it is proposed that the number of people in section of welfare service will be increased and required more professional services and support. Vietnam is trying to build the welfare system which is based on (a) welfare rights in specific social and economic conditions, (b) the welfare coverage for all individuals with diversity solutions; (c) the specific concerns for the vulnerable groups such as the poor, the disabled people, ethnic groups, the unemployed, the older persons, the migrants, and victims of natural disasters; (d) empowered approach in aspects of indirect support to sustainable development; and (e) the role of the State on administrating as well as the role of the social organisations in practice which widens the number of stakeholders on this welfare reform (Viện KHLĐXH 2010).

Currently, there are research projects and papers on identifying social work as a new profession in Vietnam. These include requirements for its development, its new definition and professional standards, social need and requests to have social work services for particular topics. These researches are most needed since the first batch of the master of social work students from Vietnam National 
University-Hanoi and Vietnam Graduate Academy of Social Sciences completed their final thesis in 2013 and 2014, which contributed to the current social work research. However, there is still lack of research on looking at opportunities and challenges for social work education from the voices of students and the graduates in order to have comprehensive views on the development of social work in Vietnam. Getting the direct voice of students in social work programs will be significant, which support the educators and managers of social work programs to make the eligible changes for better outcomes of social work education in Vietnam. This exploratory research contributes to such gap on the research of social work development in Vietnam. The results can generate suggestions for the development of the Social Work profession in Vietnam, by year 2020. The research questions raised in this paper are: What is the rationale of the social work education in Vietnam in terms of programs, learning materials and teaching staff? How students experienced current condition of social work education in Vietnam? How do they find the challenges and difficulties posed by the development of the social work profession in the Vietnamese context?

\section{Theoretical Approach and Research Methods}

This research is driven by the theoretical perspective of social constructionism. Constructionism considers the meaning of social fact. To regard social fact that is socially constructed is to focus on its dependence on contingent aspects of social selves. Constructionism also considers how social phenomena operate in particular social settings. The meaning of phenomena is not discovered but can be constructed. Crotty claims that meanings are constructed by human beings as they participate in the world they are interpreting (Crotty 1998). By application of the social constructionism, the challenges of social work education are generated by the voices of social work students rather than from the research point of views only. Additionally, the development of social work and its education in Vietnam is socially constructed in specific conditions in Vietnam.

In looking at the voices of social work's students, this research utilizes as main research methods the document analysis and the survey to get the students' voices on social work education in Vietnam. The first one identifies the current structure of social work program at undergraduate levels and updated research on promoting social work professionally and academically in Vietnam. The second one focuses on the voice of students on different aspects of structure of training program, staff on social work education, its materials and fieldwork requirement. Data on the voices of students on assessing the skill training for students is also collected through the survey.

The survey collected data from 360 students across Vietnam randomly, from 17 institutions among 50 universities and colleges currently training social work program. This survey invokes free participation, which identified both the voices of undergraduate and graduate program students (those who graduated in bachelor in social work and currently attending the Masters program) in social work. The questions for collecting the data are as follows: (a) How students assess the structure of program and the rationality of structure in different layers?; (b) How students assess the learning materials for social work education? What is the quality of lecturers and social work staff? (c) What are difficulties on doing fieldwork? (d) What is the student's voice on prospects of Vietnam social work education?

\section{Research Samples}

Table 1. Sample of the survey

\begin{tabular}{ccc}
\hline Research samples & $\mathbf{N}=\mathbf{3 6 0}$ & $\mathbf{\%}$ \\
\hline Gender & 360 & 100 \\
Male & 250 & 69.4 \\
Female & 110 & 30.6 \\
Age group: youngest: 18; oldest: 29 & 360 & 100 \\
Under 22 & 220 & 61.1 \\
Above 22 & 140 & 38.9 \\
Academic Year & 360 & 100 \\
First year & 40 & 11.1 \\
Second year & 45 & 12.5 \\
Third year & 100 & 27.8 \\
Fourth year & 70 & 19.4 \\
Graduated & 105 & 29.2 \\
Being students of social work program & 360 & 100 \\
Directly approved by academic merit & 5 & 1.4 \\
First choice & 235 & 65.3 \\
Not a first choice & 120 & 33.3 \\
Social work program's orientation & 355 & 100 \\
By parents & 15 & 4.2 \\
By relatives & 40 & 11.3 \\
By themselves & 270 & 76.1 \\
No choice & 30 & 8.3 \\
\hline
\end{tabular}

This paper is guided by the research ethics in Vietnam such as voluntary research participation in the survey. There is no coercion of the participants. All personal information is recorded without identification. All participants signed the informant forms for their participation before the survey is conducted. Sampling for this survey is convenience and random which was conducted from January to April 2014.

\section{The Context of Social Work Education in Vietnam}

This section provides the overview of the history of the social work education in Vietnam and recent government efforts to develop social work education in Vietnam:

\section{History of the Social Work Education in Vietnam}

The history of social work education in Vietnam evolved into two main developmental areas. In the South, before 1975, particularly in Sai Gon (Ho Chi Minh City at present), there were some social work training institutions such as 
Caritas and National School of Social Work. The Caritas was established by French Red Cross in 1948 based on the Vinh Son Caritas (1942) (Kham, 2011). The first training course for social workers was opened in 1948 with 10 participants. Then, this institution had been responsible for training female social workers. The National School of Social Work was established afterward, which had the mission of training skilled social workers for human services at that time. After 1975, the Open University in Ho Chi Minh City which was the first institution in Vietnam started training undergraduate students and provided great contribution on training professional social work as well as ensuring the continuity of social work education in Vietnam. In the North of Vietnam, after the August Revolution in 1945, the Government issued a wide range of policies and strategies for developing the social work activities and practices (Oanh 2002; Lịch 2010). During the Independence Declaration (1945), President Ho Chi Minh made statements on human rights, justice, and happiness for all individuals. There were another critical polices on orphan social care, social support for the disabled person, the elder and the poor; and also created the favorable conditions for them to develop themselves and to contribute to social development (Kham, 2011).

Along with the national history on war time and on the reconstruction time, a wide range of social organizations such as the Youth, the Women, the trade union, the Red Cross, churches, pagoda and charity organizations also delivered various activities for supporting the vulnerable people and groups which were a significant background for social work education and practice in Vietnam. Despite the fact that the content of the professional social work had not been cleared in educational system, social work activities provided great contributions in the developments of individual, family and community on overcoming the difficulties and strengthening the welfare policies and practice (Kham 2011, Hà 2012).

The development of social work after 1986 was more critical, with more concerns in terms of policies and practice. There were a series of short training courses on specific skills for people working in social work area and human services. In addition, there were also significant concerns from international organizations and NGOs in Vietnam about the development of social work education.

The "Doi Moi" (Renew) policy in 1986 brought social change and development in the country, which aimed at rapid industrialization, modernization and the creation of a market economy. Over the last three decades, Vietnam has made great achievements through the rise of living standards and the decrease of the poverty rate from $60 \%$ in 1990 s to $25 \%$ recently (Vietnam Government 2010). This economic growth has brought many social benefits, including the capacity to develop infrastructure in education and health, but at the same time it has also created some new social problems. The first group of social problems concerns the social protection, which includes the poor, children in need of social protection (street children, disabled children, children suffering from abuse and neglect); adult with disabilities, older people who are living without assistance from their family and relatives. The second group of problems referred to as social evils, including trafficking children and young women, people with HIV/AIDS, drug misuse, prostitution and crime (Hugman, Lan \& Hong 2007). Social work practice is regarded as the most significant catalyst for promoting social protection and for reducing social problems. It is estimated that nearly $30 \%$ of the Vietnamese population currently need social work services and practices (Kham, 2011).

Social work was officially established and training at the undergraduate level in university commenced in 2004. After 10 years of its approval, 56 universities and colleges have been accepted for training of social work students (Bộ Giáo dục và Đào tạo 2014). As the new professional activities, social work education faced the challenges and the prospects for future development, especially after the Government approved the Strategy for Social Work development to 2020 and National strategy for social development to 2020 which was modified particularly in the Welfare Reform to 2020.

In looking at social work education and practice in Vietnam, there are some ideas about its developments in terms of: (a) Social work in Vietnam has its origins from social welfare practice and social protection. It is similar to the first stage of social work development in other countries. In fact, social work activities have a long history in terms of the support for individuals, groups, and communities and from the government, which are delivered in charity approach and based on the traditional values of the Vietnamese. Basing on social protection and social welfare practice, the theoretical background for social work education and practice in Vietnam originated from other disciplines of social sciences, especially from sociology, psychology, anthropology and policy sciences. (b) Social work in Vietnam has been changing its model from responding activities to professional activities. The initial activities are in terms of charity or favor activities, especially in the feudal time in Vietnamese history (Oanh 2002). These activities have changed to individual, community and State based responsibilities in addressing to natural disasters, vulnerable groups and people in high demand for support. The professional activities have been recently presented and applied for last two decades since the introduction of social work's education and practice in human life from 2004. (c) Aiming at professional social work, there are various activities delivered annually in aspects of: short courses or training social workers and teachers in social work; annual conferences on social work education and practice by schools of social work, and strategy for social work development as well as the decision on making the code of social workers in labor force.

\section{The Strategy for Social Work Development in Vietnam to 2020}

In 2010, the Vietnamese Government approved the Strategy for social work development with the total budget of up to 2.340 billion VND (approximately 112 million 
USD). This strategy aims at developing social work professionally and widely (Hùng 2010). The strategy is divided into two main phrases. The first one from 2010-2015 aims at: (a) setting up the codes for social workers in labor force, the ethical standards and the standards of social work services; (b) making up, amending and updating social policies and legal documents on social work development; (c) developing the social work staff which will be increased at $10 \%$ by 2015 such that there will be one or two social workers at commune level; (d) setting up at least ten pilot centers on social work services at district level; (e) training and strengthening social work skills for at least $50 \%$ of those working in social work positions at commune level and related organizations; (f) setting up and reviewing the curriculum and its contents on social work education at all levels from vocational training to master levels; strengthening the abilities of social work lecturers and trainers; and $(\mathrm{g})$ increasing the social awareness on social work. There are also five other tasks for the second phrase, aiming at (a) establishing and approving the professional standards for social work staff in specific social work services; upgrading the legal and policy documents on social work development; (b) increasing $50 \%$ of social work staff at all levels; enlarging the examples of social work centers at district levels; (c) training and retraining the social work skills for at least $50 \%$ of those working as social workers at commune level; social work centers and organizations of social work services; (d) socializing social work practice with the participations of NGOs, individuals and institutions nationally and internationally in both education, training and delivering social work services; (f) continuing the task of increasing social awareness on social work.

The strategy also identifies the high demand for human resources for social work education. It is estimated that 60 thousands of social work staff need training and retraining with professional skills; 35 thousands are needed at professional education setting and, from various levels of vocational training. At the first stage of social work development, the strategy also focuses on specific groups such as the older, the disabled people, the orphan children, people with HIV/AIDS, the drug abused and other groups (Hùng 2010; Hà 2010). The strategy is a comprehensive solution for promoting social work professionally and it is also socially constructed basing on the specific social and economic conditions in Vietnam.

After 4 years of strategy, during the national conference on "Implementation of the Project 322 on professionalising social work in Vietnam" in early August of 2014 by Ministry of Labor, the Invalids and Social Affairs concluded that Vietnam achieved great outcomes in social work development in terms of having legal documents for identifying the social work career professionally, training staff and social workers, establishing the social work centers at provincial and district levels, and so on. However, it was observed that there are still limitations in areas of social awareness on social work, lack of efficacy, and legal basis for social workers at community, recruitment of graduate students on social work, lack of social attention on social work activities of the provincial and district centers.

\section{Research Findings}

The findings about the challenges of social work education in Vietnam from the voices of students include the following: program assessment, prospect for social work, changes or not changes.

\section{Assessment on the Structure of Program, Learning Material and the Lecturers}

In Vietnam, the undergraduate program developed based on the core curriculum by Ministry of Education and Training. The undergraduate program must contain five course blocks namely: general courses, fundamental courses, basic courses, social work (profession) courses and supported (skill) courses.

The survey, collecting the voices of social work students on challenges for social work development, is implemented to 360 respondents with $69.4 \%$ male students. Students are distributed according to their year levels, $11.1 \%$ are from the first year students, while the second year, third year, fourth year and graduate students are $12.5 \%, 27.8 \%, 19.4 \%$ and $29.2 \%$ respectively. Notably, there is only $1.4 \%$ of respondents selected to be student with academic merits, while $65.3 \%$ of them were students who considered Social Work as their first choice and the rest regard Social Work as their second choice. Students of social work are career oriented who decided mostly by themselves $(76.1 \%)$, while their parents with only $4.2 \%$ decide it.

Evaluation on the program structure and its significant: The structure of undergraduate program is developed based on the core program issued by the MOET. Such development is different from institutions compared to their conditions, staff, and mission. The questions included for student's assessment are: How do you assess the rationality of program in different layers of the general courses, fundamental courses, basic courses, social work courses and supported courses? The Cronbach's Alpha statistics revealed that the six questions regarding program assessment of social work, was computed at 0.811 , which means that questions are well designed.

Table 2. Means value on program assessment

\begin{tabular}{cccccc}
\hline \multirow{2}{*}{$\begin{array}{c}\text { Assessment } \\
\text { on }\end{array}$} & Means & \multicolumn{2}{c}{ Gender } & \multicolumn{2}{c}{ Students } \\
\cline { 3 - 6 } & & Male & Female & $\begin{array}{c}\text { Under } \\
\text { graduate }\end{array}$ & Graduate \\
\hline $\begin{array}{c}\text { Whole } \\
\text { program } \\
\text { General }\end{array}$ & 3.26 & 3.24 & 3.32 & 3.25 & 3.29 \\
$\begin{array}{c}\text { courses } \\
\text { Fundamental } \\
\text { courses }\end{array}$ & 3.44 & 3.48 & 3.36 & 3.41 & 3.52 \\
$\begin{array}{c}\text { Basic courses } \\
\text { Profession }\end{array}$ & 3.78 & 3.76 & 3.45 & 3.55 & 3.57 \\
$\begin{array}{c}\text { courses } \\
\text { Skill courses }\end{array}$ & 3.46 & 3.28 & 3.86 & 3.80 & 3.71 \\
\hline
\end{tabular}

Chi-square test with $\mathrm{p}<0.05$ in all variables by students and gender 
In looking at the means value ( 1 is very irrational, while 5 is very rational), it was found out that the responses are positive with the "basic courses of the program", at 3.78, while its values for the general courses is at 3.26. The average value is above the normal. There is small difference between undergraduate students and graduate students with higher assessment on the professional courses by graduates. In looking at the chi-square values between such assessment and student indicator, all are significant at $\mathrm{p}<0.05$, so there is correlation between variables on the assessment.

Evaluation on learning materials: This assessment was also applied in the 5 course blocks of the program using Likert scales of 1-5 where 1: not very good and 5: very good. The Cronbach's Alpha of these 5 questions is 0.907 confirming that the questions are well-designed. The means values are presented in the following table with comparison between two main independent variables of gender and student:

Table 3. Means value of learning material assessment

\begin{tabular}{|c|c|c|c|c|c|}
\hline \multirow{2}{*}{$\begin{array}{l}\text { Assessment } \\
\text { on learning } \\
\text { materials of }\end{array}$} & \multirow{2}{*}{ Means } & \multicolumn{2}{|c|}{ Gender } & \multicolumn{2}{|c|}{ Students } \\
\hline & & Male & Female & $\begin{array}{c}\text { Under } \\
\text { graduate }\end{array}$ & Graduate \\
\hline $\begin{array}{l}\text { General } \\
\text { courses }\end{array}$ & 3.03 & 3.02 & 3.05 & 2.98 & 3.14 \\
\hline $\begin{array}{c}\text { Fundamental } \\
\text { courses }\end{array}$ & 3.14 & 3.15 & 3.11 & 3.16 & 3.10 \\
\hline Basic courses & 3.14 & 3.09 & 3.26 & 3.18 & 3.05 \\
\hline $\begin{array}{l}\text { Profession } \\
\text { courses }\end{array}$ & 3.03 & 2.96 & 3.21 & 3.02 & 3.05 \\
\hline Skill courses & 2.89 & 2.72 & 3.32 & 2.93 & 2.81 \\
\hline
\end{tabular}

(The means value is classified into 5 groups with each group value difference is 0.8 , so from 1.0-1.8: not very good, 1.8 to below 2.6: not good, from 2.6 to close 3.4: normal; from 3.4 to 4.2 : Good; and above 4.2 : Very good)

Student assessment on the materials for such course blocks of the program, such as the fundamental courses and basic courses of social work, is also positive since it is above the normal line, except the value of course for training skills, with the higher values on the basic and fundamental courses, at 3.14. The lowest one is for the skill courses, at 2.89. So, the assessment of students on learning material is at the "normal" only. That seems to be compatible with current situation of social work development in Vietnam as there is a small number of textbook titles on social work for both bachelor and master programs in social work, while students are less capable on reading the materials in English.

Assessment the quality of lecturers in terms of knowledge, attitudes and skills: for all lecturers (teaching the social work courses, skills courses and fieldwork ones), the mean values of the attitudes are the highest, while that of skill is the lowest:
Table 4. Means values on assessing knowledge, skill and attitude of social work

\begin{tabular}{ccccccc}
\hline \multirow{2}{*}{ Lecturers of } & \multicolumn{2}{c}{ Knowledge } & \multicolumn{2}{c}{ Skill } & \multicolumn{2}{c}{ Attitude } \\
\cline { 2 - 7 } & Means & $S D$ & Means & $S D$ & Means & $S D$ \\
\hline $\begin{array}{c}\text { Background } \\
\text { courses }\end{array}$ & 3.70 & .054 & 3.62 & .050 & 4.07 & .046 \\
$\begin{array}{c}\text { Skill courses } \\
\text { Fieldwork/ } \\
\text { practical }\end{array}$ & 3.63 & .048 & 3.58 & .049 & 3.95 & .048 \\
\hline
\end{tabular}

(The means value is classified into 5 groups with each group value difference is 0.8 , so from 1.0-1.8: not very good, 1.8 to below 2.6: not good, from 2.6 to close 3.4 : normal; from 3.4 to 4.2 : Good; and above 4.2 : Very good)

It seems that there is lower assessment on the means of social work lecturers in those courses providing students with skill and fieldworks by all in terms of teachers' knowledge, skill and attitudes to social work. Overall, students have their assessment on lecturers at around level of "good", except the skill of fieldwork teachers. That assessment is socially constructed as at the moment there are discussions about how to develop the practice, fieldwork efficiently as there are lack of such working staff in the community and placement in social work education.

Assessment about the implementation of placement: Placement is an important part of the four year training program of social work in Vietnam. In almost all universities with social work training, the placement is normally implemented at the final years from 6 to 8 weeks in communities, workplaces which depend on the chosen topics by each student or a group of students. Student voices on this work are various as following table of mean presentation:

Table 5. Means value of placement assessment

\begin{tabular}{ccc}
\hline Assessment of placement in terms of & Means & SD \\
\hline contents & 3.71 & .058 \\
duration & 3.41 & .072 \\
timeline & 3.51 & .062 \\
place & 3.44 & .079 \\
supervision & 3.12 & .071 \\
applications & 3.20 & .063 \\
\hline
\end{tabular}

(The assessment is calculated by the 5 scales of Likert question as 1: not very rationale, 2 : not rationale; 3 : Normal; 4 : rationale and 5: very rationale. The value of the means are described as table 4)

The voices of students, the supervision's activities and the application of their knowledge and skills during the placement are at "normal". The others evaluated "rationale" by the students. So, the assessment seems quite positive about the activities of placement during the training progress of social work.

\section{Prospect of Social Work as a Profession in Vietnam}

In looking at this aspect, the survey aimed at identifying responses from the question of What do you think the development of social work in the near future? There are more responses on "not developed so fast" than "developed 
so fast" $(14.9 \%$ compared with $10.4 \%)$ while three quarters of responses $(74.6 \%)$ agreed that it will be developed if there would be changes, in terms of program, staff on social work education and fieldwork, and changes in social awareness on social work and social workers in general. Students also expect to have the professional associations (such as social workers and school of social work) as in other countries to make the bright future for social work development in Vietnam.

For the graduate students, their responses are more on the positive development with its changes. The chi-square values with value at 49.789 and its $\mathrm{p}=0.000$, shows that that there is a correlation between the requirements for social work changes and studying steps of respondents. Students respond positively more on the statement that social work will be professionally developed as it will be transformed in terms of training program, structure, lecturer and learning materials.

\section{Changes or Not and Potential Challenges}

The survey provides the option for social work students to make their decision about changing their program: If you have a chance to enter the university again, will you choose social work program? Responses from the survey shows that $68.7 \%$ of respondents will choose social work program again, worth noting is that $71.4 \%$ is responded by graduate students. It seems that social work students have developed a natural affinity to this profession in Vietnam. However, in the survey, it also got the voices of social work students about their future career challenges such as finding the social work job, working as social workers, being accredited social workers, having short courses on updating their professional skills and practices and lack of practical standards on social work for specific clients.

\section{Discussions}

Students, both undergraduate and graduate, highly appreciated the training program. It seems rationale and eligible to Vietnamese conditions as it is socially constructed based on the current situations of academic staff, fieldwork supervisors, and the existing social work developmental process in Vietnam. Social work students highly appreciated and assessed the training programs, the efforts of lecturers on social work, the learning materials, but less evaluated the role of future career and how to be professional in social work activities.

Social work students found the opportunities and challenges on social work education in Vietnam, which are compatible to overall conditions to its development as following:

In term of opportunities: (a) social demand on human resource of social work is so high for the aims of delivering welfare practice successfully. It is required to have up 2500 social workers annually. Social work is highly invested by the State and ministries on its education and application; (b) social work education has been involved with international organizations and international schools of social work. Currently, there are variety of activities on promoting social work education and training social workers and social work lecturers with the support from UNICEF, Save Children, and National University of Singapore. There are also wide ranges of workshops for social work education and practice, which contributed to the increasing social awareness on social work and enrich the support and facilities for social work education; (c) these strategies provide the legal background and social policies for social work practice in related areas, which were stated. Implementations of these strategies also make a wide and comprehensive systems of related social policies which served as a significant background for social work education and practice in the future; (d) the financial supports are very potential for social work practice and education as well as creating the wide range of social services which are bases for doing social work practicum and recruiting the human resources of social workers; and (e) social work practice will be delivered not only by the state organization but also by the individual organizations and international organization which will create the diversity of social work practice, education and collaboration and also reconstruct the quality of social work services.

While, in the aspect of the potential challenges; findings showed that (i) the social awareness on social work and social workers is still limited, which can lead to uncertainty for those want to study this subject. It can also create barriers in applying social work in practice. Social understandings on social work are known as social charity; there is also lack of specific standards and requirements on recruiting a position for social work; (ii) in the aspect of staff in social work education, there is lack of highly qualified and experienced staff with social work background; (iii) there is lack of places, institutions and experienced staff for social work practicum; (iv) the learning and teaching materials for social work education in terms of text books and guidelines are really limited. Students are unable or have difficulty to read the English materials well while the translations of foreign books and text books as well as books and textbooks in Vietnamese are hardly written; and (v) the codes for social workers in labor force were approved but there is lack of ethics codes and social worker standards in specific areas which also make the limitations on working in practice and aiming at professional activities. Social work students from the survey findings also provoke such challenges.

In order to pursue the social work developmental process professionally, it is highly required to change its training program structure and work for the improvement of lecturer staff through short-courses and collaborate with international institutions. It was also found out from the survey that social work education is required to change from generalist practice to specialized one such as to be more focused on particular topic/minor of children, disabled people, mental health, school of social work, social work in industrial zones, community development, rural social work and so on.

Social work students express their long-term commitment to social work programs, both their continuity on social work 
program and their reference for other potential students to the program. Such commitment seems to be consolidated in those graduated one.

\section{Conclusions}

The approval of the national strategy to develop social work professionally open the new development stage for social work education in Vietnam and also strive for promoting social work in becoming a professional career as in other countries. To pave the way for these strategies and practice of social work education towards the development of this professional career by 2020, there are some recommendations for the social work education in Vietnam as follows:

1. Continuing the tasks of increasing social awareness in social work and its application in practice, its role in social welfare practice and supporting the social functioning of individuals, groups and communities;

2. Reviewing and updating the social work programs at all levels which are practicable, applicable and internationalization with updated standards and ethics considerations;

3. For schools of social work: it is suggested to make the close collaboration with regional and international universities and organizations in social work at all levels in order to tap the expertise and experiences on training and practicing social work, to get a chance to enrich the learning materials and to create the network for training, researching and applying social work in specific and interested areas;

4. For lecturers in social work education: It is recommended to find the available chance for strengthening skills, upgrading English ability, attending the conferences and training workshops as well as creating the network with other staff and social workers nationally and internationally;

5. For the learners of social work programs: They should take time on identifying their eligible abilities and motivation to the social work programs; trying to make and apply relationships between theory and practice on social work; doing social work practice from first time in programs; and creating the relationships with institutions and organizations on social work practice.

\section{Competing Interests}

The author declares that he has no competing interests.

\section{Acknowledgements}

A part of this paper was presented in The Joint World Conference on Social Work, Education and Social Development, organised by IFSW, ICSW, and IASSW in Melbourne, Australia (July 2014) with support by NAFOSTED, Vietnam.

\section{REFERENCES}

Bộ Giáo dục và Đào tạo. (2013), Những điều cần biết về tuyển sinh đại học và cao đẳng năm 2013, NXB Giáo dục, Hà Nội.

Crotty, M (1998), The foundations of social research: meaning and perspective in the research process, Allen \& Uwin, Sydney.

Hà, NT. (2010). 'Đề án phát triển nghề công tác xã hội ở Việt Nam: Cơ hội và thách thức', Tạp chí Lao động và xã hội, vol. 390, pp. 37-39.

Hà, NT. (2012). "Đổi mới công tác xã hội trong nền kinh tế thị trường ở Việt Nam hiện nay", NXB CTQG, Hà Nội.

Hugman, R, Lan, NTT \& Hong, NT. (2007), 'Developing social work in Vietnam', International Social Work, vol. 50, no. 2, pp. 197-211.

Hung, NS. (2010), Đề án phát triển nghề công tác xã hội giai đoạn 2010-2020, Hà Nội.

Kham, TV. (2011). Social work education in Vietnam: Implications in the period of welfare reform, ASEAN Social Work Journal, Vol 1 , Issue 1, tr.125-135.

Lịch, NA. (2010), Giáo dục và đào tạo công tác xã hội tại Việt Nam, Đại học Đồng Tháp, pp. 6-9.

Oanh, NT. (2002). 'Historical development and characteristics of social work in today's Vietnam', International Journal of Social Welfare, vol. 11, no. 1, pp. 84-91.

Viện KHLĐXH. (2010). Đánh giá chung về thực trạng ASXH giai đoạn 2001-2010, Hanoi, viewed 28 March 2011,<http:/www.ilssa.org.vn/NewsDetail.asp?NewsId=140\&Cat $\mathrm{Id}=32>$.

Vietnam Government. (2010). Vietnam's 2011-2020 Social Economic Development Strategy, Hanoi, viewed 12 January 2011, $<$ http:/hanoi.gov.vn/web/guest/home $>$. 